\title{
Genetic variation of Oratosquilla oratoria (Crustacea: Stomatopoda) across Hong Kong waters elucidated by mitochondrial DNA control region sequences
}

\author{
KAREN K.Y. LUI, PRISCILLA T.Y. LEUNG, W.C. NG AND KENNETH M.Y. LEUNG \\ The Swire Institute of Marine Science, and Division of Ecology \& Biodiversity, School of Biological Sciences, \\ University of Hong Kong, Pokfulam, Hong Kong, People's Republic of China
}

\begin{abstract}
The population genetic structure of the mantis shrimp, Oratosquilla oratoria, in Hong Kong waters was determined using 923 base pairs of mitochondrial DNA control region sequences. Samples were collected from six localities including the openwaters and sheltered bays in both the eastern and western waters of Hong Kong. Twenty-seven haplotypes were detected in 99 individuals. A high overall haplotype diversity $(\mathrm{h}=0.886)$, with a low nucleotide diversity $(\pi=0.0026)$, was observed, and the haplotype minimum spanning network suggested that rapid expansion might have occurred among the total stomatopod population. Genetic homogeneity was observed over a meso-scale distance $(80-100 \mathrm{~km})$ whilst there were significant genetic differentiations between all pairs of the six samples. Partition of genetic variability based on hydrographic conditions did not reveal significant differentiations between: (1) eastern and western waters; and (2) open-waters and sheltered bays; but showed high levels of variation both within groups and within samples. Unexpectedly, genetic distance did not correlate with hydrographic distance among the samples. Results demonstrated a genetic patchiness pattern of $\mathrm{O}$. oratoria in Hong Kong waters that may be attributable to the interplay between hydrographic conditions (e.g. salinity) and the species' life history traits.
\end{abstract}

Keywords: stomatopod, genetic patchiness, Hong Kong waters, Crustacea, control region

Submitted 23 March 2009; accepted 18 July 2009; first published online 19 October 2009

\section{INTRDDUCTION}

Many marine invertebrates have planktonic larvae which are dispersed by ocean currents (McEdward, 1995). These species are likely characterized by low levels of genetic differentiation (i.e. high homogeneity) among populations over broad spatial scales, but it has become apparent that significant genetic differentiation does exist among different populations in some species (see Palumbi, 2003 for a review). This could be linked to a restricted larval dispersal ability (Tzeng et al., 2004), mostly by selection (Hedgecock, 1986) or behavioural differences (Burton \& Feldman, 1982), and environmental factors, such as oceanic circulation patterns and hydrographic conditions, which create physical barriers and subsequently limit gene flow (Palumbi, 1994; Perrin et al., 2004). Studies on the relative importance of these factors on population genetic structure are crucial to our understanding of the impact of environmental changes on the ecological functioning of different populations, as well as the management of marine resources (Palumbi, 2003). In particular, the significance of intraspecific genetic diversity, including diversity among and within populations, has been emphasized with a view to conserving genetic resources (Kenchington et al., 2003).

Corresponding author:

P.T.Y. Leung

Email: tyleung@graduate.hku.hk
Stomatopods are widely distributed in both temperate and tropical regions (Ahyong, 2001), and the planktonic stage of their larvae can last for 2-3 months (Provenzano \& Manning, 1978; Morgan \& Goy, 1987). Whilst the dispersal potential of stomatopod larvae is expected to be high (Barber et al., 2002a), Reaka \& Manning (1981) believed that such larvae do not appear to disperse over long distances as reflected by their limited geographical ranges. Haptosquilla glyptocercus, for example, showed larval dispersal and recruitment over large spatio-temporal scales, resulting in high genetic diversity (Barber et al., 2002a). Conversely, Barber et al. (2002b) used genetic techniques to infer dispersal history among populations of the benthic reef stomatopod, Haptosquilla pulchella, and detected significant genetic differentiation over relatively short distances $(300 \mathrm{~km})$ in the Indo-Pacific, despite an estimated long planktonic larval period ( $4-6$ weeks). These aforementioned studies suggest that larval dispersal scales and genetic variation among populations are likely to be species specific in the Stomatopoda. However, with limited data, the genetic structure and larval dispersal potential of many stomatopods remains largely unknown.

Oratosquilla oratoria (Squillidae) is a common, commercially important, stomatopod in the Indo-West Pacific region (Ahyong, 2001). A recent field study showed that it is one of the most abundant benthic crustaceans in Hong Kong waters (Lui et al., 2007). In Hong Kong, the abundance of $O$. oratoria in western waters was consistently higher than 
in eastern waters, i.e. $\sim 4$-fold difference in average monthly abundance. The reduced abundance in eastern waters could be ascribed to episodic hypoxia events during August and October (Lui, 2005). Laboratory-reared larvae of O. oratoria have a planktonic stage of between 36 and 59 days (Hamano \& Matsuura, 1987). Larvae may be able to disperse over great distances during such a relatively long planktonic period and, thus, the degree of genetic differentiation among populations is expected to be low. There is, however, a lack of field-based population genetic studies to verify this postulation. Sequencing analysis of mitochondrial (mt) DNA is one of the most common methods to detect genetic differentiation (Bagley \& Gall, 1998; Refseth et al., 1998), and the mtDNA control region with a generally high rate of base substitutions makes it a suitable marker for studies of intraspecific population genetics (Meyer, 1994). The present study aimed to examine the genetic structure within and among six samples of $O$. oratoria in Hong Kong waters, using mtDNA control region sequences.

\section{MATERIALS AND METHODS}

\section{Sample collection}

Individuals of Oratosquilla oratoria were collected from the eastern (two stations in Tolo Harbour, E1 and E2, $\mathrm{N}=34$ ) and western (two stations off southern Lantau Island, W1 and $\mathrm{W}_{2}, \mathrm{~N}=35$ ) waters of Hong Kong using a commercial shrimp trawler (beam size: $1.5 \mathrm{~m}$; stretched mesh size: $2 \mathrm{~cm}$ ), from June to July 2004 (Figure 1). Oratosquilla oratoria individuals were also collected from two locations in Hong Kong's surrounding waters $(\mathrm{N}=30)$, i.e. near Neilingding Island (China-West, CW) and Dalu Wan (China-East, CE) (Figure 1). Samples were kept alive in the aquarium before DNA extraction.

\section{DNA extraction}

Approximately $100 \mathrm{mg}$ muscle tissues were dissected from the fifth abdominal somite of each individual. Tissues were washed with sterile distilled water, cut into small pieces, and transferred to $1.5 \mathrm{ml}$ centrifuge tubes containing $500 \mu \mathrm{l}$ lysis buffer (100 mM Tris-HCL, pH 8.0, 20 mM EDTA, 1.4 $\mathrm{M} \mathrm{NaCl}, 2.0 \%$ hexadecyltrimethylammonium bromide $(\mathrm{CTAB}))$. Each tissue sample was incubated and digested overnight at $55^{\circ} \mathrm{C}$ with $45 \mu$ l proteinase $\mathrm{K}\left(1 \mathrm{mg} \mathrm{ml}^{-1}\right)$, and the total genomic DNA was then extracted using the phenolchloroform extraction method (Hoelzel \& Green, 1992). The extracted DNA pellets were resuspended in $50 \mu \mathrm{l}$ TE buffer (10 mM Tris-HCl, pH 8.o, 1 mM EDTA, $\mathrm{pH}$ 8.0) and stored at $4{ }^{\circ} \mathrm{C}$ before DNA amplification.

\section{DNA amplification and sequencing}

A DNA segment of $\sim 1100$-base pairs (bp; including the control region) was amplified by polymerase chain reaction (PCR) using a pair of primers, CR-F1 ( $5^{\prime}$-TAACCGCGACTGCTGGCAC $\left.3^{\prime}\right)$ and CR-F2 (5'-GGGTATGAGCCCATTAGCTT- $\left.3^{\prime}\right)$ which were designed from the corresponding position of 13298 and 14772, respectively, of the blue crab Portunus trituberculatus $\mathrm{mt}$ sequence (from GenBank-Accession number: AB093006). PCR amplifications were carried out in a PTC-100 Thermocycler (MJ Research, USA). Thirty amplification cycles, each consisting of an initial DNA denaturation step of 2 minutes at $94^{\circ} \mathrm{C}$, denaturation at $94^{\circ} \mathrm{C}$ for 1 minute, annealing at $56^{\circ} \mathrm{C}$ for 45 seconds, and extension at $72^{\circ} \mathrm{C}$ for 75 seconds, were performed. A 5 minute extension at $72^{\circ} \mathrm{C}$ was included in the final cycle. Reagents ( $50 \mu \mathrm{l}$ in volume) contained 20 ng of template DNA, 1 unit of Taq DNA polymerase (Invitrogen ${ }^{\text {TM }}$ Life Technologies Co.), $0.5 \mu \mathrm{M}$ of each primer, $0.2 \mathrm{mM}$ of each dNTPs (dATP, dCTP, dGTP and dTTP), $1.5 \mathrm{mM} \mathrm{MgCl}_{2}$ and $1 \times \mathrm{PCR}$ buffer $(200 \mathrm{mM}$ Tris- $\mathrm{HCl}, \mathrm{pH}$ $8.4,500 \mathrm{mM} \mathrm{KCl})$.

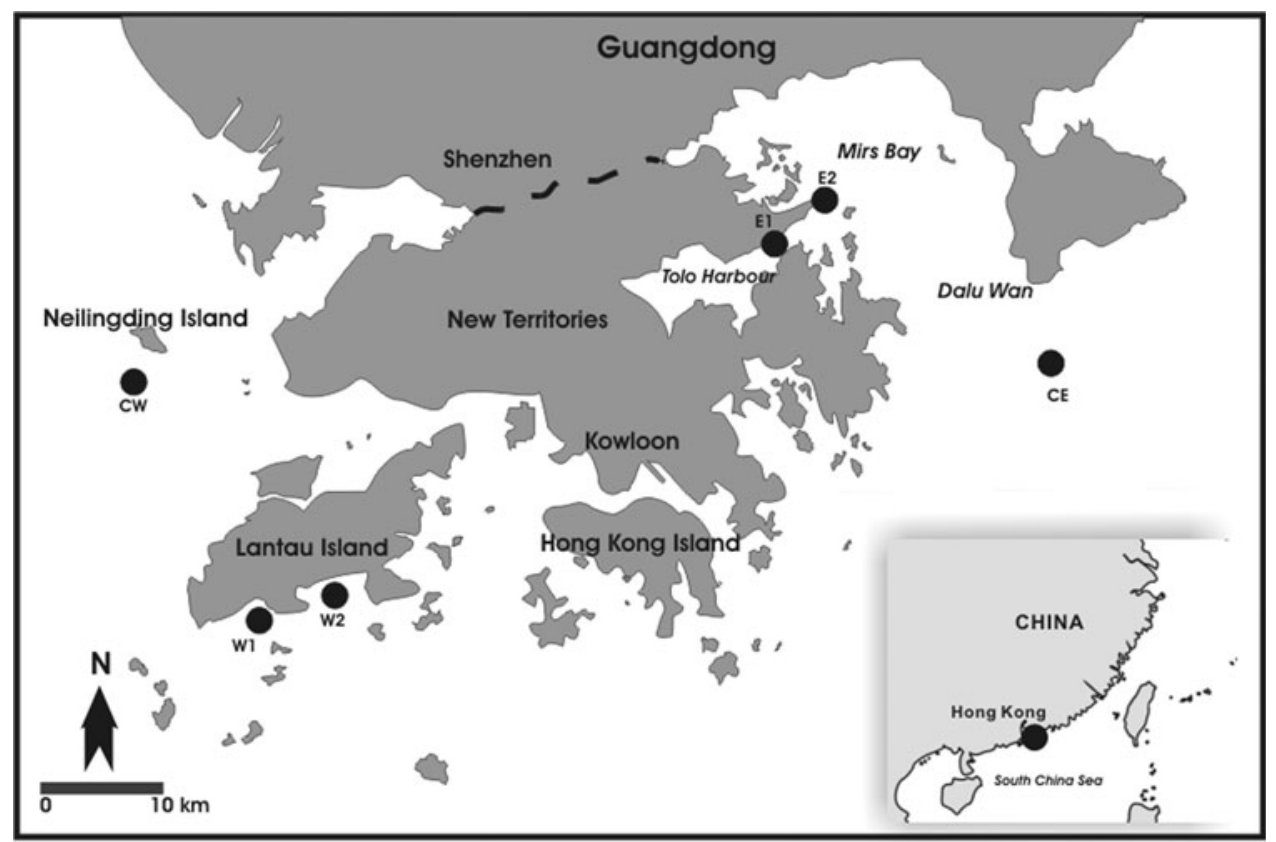

Fig. 1. Sampling locations for Oratosquilla oratoria in Hong Kong and surrounding waters: eastern waters: E1, E2 and CE; western waters: W1, W2 and CW. 
An aliquot of $2 \mu \mathrm{l}$ of each amplification was electrophoresed on a $1.5 \%$ agarose gel to check for the correct fragment size, and to ensure only a single amplification product was obtained. PCR products were purified using the GFX PCR purification kit (GE Healthcare Bioscience, USA), following procedures outlined by the manufacturer. Cycle sequencings of the PCR product $(\sim 1100 \mathrm{bp})$ were performed using the sequencing BigDye ${ }^{\circledR}$ Terminator V 3.1 Sequencing Standard Kit (Applied Biosystems, USA), and conducted using the same pair of forward and reverse primers applied in the initial PCR reaction. The sequencing PCR products were then purified using AutoSeq $96^{\text {TM }}$ Plate (GE Healthcare Bioscience, USA). Purified products were analysed by capillary electrophoresis using an Applied Biosystems Model 3730 automated DNA analyser (Perkin-Elmer, USA), in the Genome Research Centre of the University of Hong Kong.

\section{Data analysis}

Chromatograms obtained from the automated analyser were read, and sequences were assembled using the sequence editing software SeqMan (DNASTAR Inc., Denmark). The resulting consensus sequences were aligned using Mega 3.1 (Kumur et al., 2004). Haplotype diversity ( $h$; Nei, 1987) and nucleotide diversity ( $\pi$; Tajima, 1983) were calculated using ARLEQUIN v. 3.1 (Excoffier et al., 2005). The same program was used to calculate genetic differentiation between the six samples using the pairwise F-statistics (Wright, 1951) by performing 10,100 permutations.

Analysis of molecular variance (AMOVA) was performed using ARLEQUIN to examine hierarchical population structure by pooling the samples into two different groupings: (1) eastern (EW: CE, E1 and E2) and western (WW: CW, $\mathrm{W}_{1}$ and $\mathrm{W}_{2}$ ) waters; and (2) open-waters (OW: CE, CW) and sheltered bays (SB: $\mathrm{W}_{1}, \mathrm{~W}_{2}, \mathrm{E}_{1}$ and $\mathrm{E}_{2}$ ). Sixteen thousand permutations were executed to guarantee $<_{1} \%$ difference with the exact probability in $99 \%$ of cases (Guo \& Thompson, 1992). Relationships among haplotypes were analysed in a parsimony network (TCS v. 1.12; Clement et al., 2000), using the statistical parsimony procedure (Crandall et al., 1994). This method estimates the unrooted tree and provides a $95 \%$ plausible set for all sequence type linkages within the unrooted tree. A minimum spanning network tree was then produced. The relationship between geographical distance, which was estimated as the shortest pelagic distance between pairs of samples, and the pairwise $F_{\mathrm{ST}}$ values was tested by Mantel's test for permutation procedure (ARLEQUIN v. 3.1).

\section{RESULTS}

\section{Genetic diversity}

Sequence analysis of a 923 bp region of the mtDNA control region showed there to be 27 unique haplotypes in the 99 Oratosquilla oratoria individuals, with a total of 14 polymorphic sites (Table 1). Haplotype (Hap) 1 of the sequences has been deposited in the GenBank database (Accession number: DQ120060). The haplotype diversity $(h)$ ranged from o to 0.952 (Table 2 ). An overall high haplotype diversity was recorded (mean $h=0.886$; Table 2). Across all six stomatopod samples, those from eastern waters showed high to moderate $h$ values ( 0.588 to 0.952 ) with the number of haplotypes ranging from 3 to 6 . However, extremely high and low $h$ values were obtained for western waters. A high $h$ (o.949) with sixteen haplotypes was recorded in the CW sample while only a single haplotype (Hap 27) with $h=0.000$ was found in $W_{1}$. Nucleotide diversity $(\pi)$ ranged from o to 0.0035 , although the within site value was quite low (mean $\pi=0.0026$; Table 1). Relationships between haplotypes were shown on a haplotype minimum spanning network (MSN; Figure 2). The MSN displayed a star-like genealogy dominated by a few haplotypes connecting to other haplotypes by few mutations (Figure 2). The most common haplotype, Hap 21, was shared by a total of 24 individuals from E1, E2 and W2. No obvious pattern with haplotypes mixing from the eastern and western waters within the MSN was observed (Figure 2A). Total haplotype numbers from the eastern and western waters were 13 and 18, respectively. Among these, five of the haplotypes were shared.

When samples were classified into two groups, i.e. sheltered bays (SB) and open-waters (OW), Oratosquilla oratoria samples from the former had a relatively lower haplotype number and nucleotide diversity (range: $h=0-0.684, \pi=$ $0-0.0012$ ) than those from the latter (range: $h=0.949-$ $0.952 ; \pi=0.0033-0.035$; Table 2). Among the 27 haplotypes, samples from SB shared 9 haplotypes whilst those of OW shared 20 haplotypes (Figure $2 \mathrm{~B}$ ). Only two haplotypes (Hap 4 and Hap 15) overlapped between the two groups. Within the OW group, although the two samples (CE and $\mathrm{CW}$ ) possessed high haplotype diversity, only two haplotypes (Hap 1 and Hap 5) were shared (Figure 2A).

\section{Genetic differentiation within and among samples}

A significant genetic differentiation was detected between each pair of the six samples, except between the pair of CE and $\mathrm{CW}$ (pairwise $F_{\mathrm{ST}}=0.007, P>0.05$; Table 3). The highest pairwise $F_{S T}$ was found between $\mathrm{W}_{1}$ and $\mathrm{W}_{2}$, despite the fact that these regions were geographically close. Pairwise $F_{\mathrm{ST}}$ values were, in general, higher between the two western SB samples ( $\mathrm{W}_{1}$ and $\mathrm{W}_{2}$ ) and other samples (Table 3). The Mantel test showed that there was no significant correlation between linearized $F_{S T}$ and hydrographic distances between different samples $(r=-0.078, P>0.05$; Figure 3).

Samples from the six localities were analysed using AMOVA by dividing them into groups according to hydrographic conditions: i.e. (1), eastern and western waters (EW and WW) and (2), open-waters and sheltered bays (OW and SB) as described above. Such partitioning did not reveal significant differentiation among the groups (Table 4). Instead, high and significant variation was present among samples within groups $(38.8 \%$ and $39.8 \%$, both $P<0.001)$ and within samples $(63.6 \%$ and $64.2 \%$, both $P<0.001)$.

\section{DISCUSSION}

In the present study, Oratosquilla oratoria generally displayed a meso-scale genetic homogeneity but had a micro-scale genetic divergence between samples collected from across 
Table 1. Variable sites of the 27 haplotypes and their frequencies in each sample of Oratosquilla oratoria. Dots represent the same base as haplotype 1.

\begin{tabular}{|c|c|c|c|c|c|c|c|c|c|c|c|c|c|c|c|c|c|c|c|c|}
\hline \multirow[t]{2}{*}{ Haplotype } & \multicolumn{14}{|c|}{ Position of polymorphic sites in the 932 bp sequence } & \multicolumn{6}{|c|}{ Sample } \\
\hline & 51 & 52 & 74 & 152 & 237 & 325 & 351 & 473 & 523 & 558 & 642 & 818 & 819 & 905 & E1 & E2 & W1 & $\mathbf{W}_{2}$ & $\mathrm{CE}$ & CW \\
\hline 1 & G & A & G & $\mathrm{C}$ & $\mathrm{C}$ & $\mathrm{T}$ & $\mathrm{T}$ & $\mathrm{C}$ & A & $\mathrm{T}$ & A & A & $\mathrm{T}$ & $\mathrm{T}$ & & & & & 1 & 5 \\
\hline 2 & . & G & . & . & $\mathrm{T}$ & & $\mathrm{C}$ & . & . & $\mathrm{C}$ & . & . & . & . & & & & & 2 & \\
\hline 3 & . & . & . & $\mathrm{T}$ &. & . & . & . & G & C & . & . & . & . & & & & & 1 & \\
\hline 4 & . & . & . & . & $\mathrm{T}$ & . & . & . & . & . & . & . & . & . & & & 18 & & 1 & \\
\hline 5 & . & G & . & $\mathrm{T}$ & $\mathrm{T}$ & & C & . & G & C & . & . & . & . & & & & & 1 & 2 \\
\hline 6 & . & . & . & & . & . & C & . & . & . & . & . & . & . & & & & & 1 & \\
\hline 7 & . & G & . & $\mathrm{T}$ & $\mathrm{T}$ & & . & . & G & . & . & . & . & . & & & & & & 1 \\
\hline 8 & . & . & . & . & . & . & . & . & G & C & . & . & . & . & & & & & & 1 \\
\hline 9 & . & G & . & $\mathrm{T}$ & $\mathrm{T}$ & . & C & . & . & C & . & . & . & . & & & & & & 2 \\
\hline 10 & . & $\mathrm{G}$ & . & $\mathrm{T}$ & $\mathrm{T}$ & & . & . & G & C & . & . & . & . & & & & & & 1 \\
\hline 11 & . & . & . & . & $\mathrm{T}$ & . & C & . & G & C & . & . & . & . & & & & & & 1 \\
\hline 12 & . & G & . & . & $\mathrm{T}$ & . & . & . & G & C & . & . & . & . & & & & & & 1 \\
\hline 13 & . & G & . & $\mathrm{T}$ & $\mathrm{T}$ & & . & . & . & C & . & . & . & . & & & & & & 1 \\
\hline 14 & . & . & . & $\mathrm{T}$ & . & . & . & . & G & . & . & . & . & . & & & & & & 2 \\
\hline 15 & . & . & . & $\mathrm{T}$ & $\mathrm{T}$ & . & . & . & . & . & . & . & . & . & & 8 & & & & 1 \\
\hline 16 & . & G & . & . & $\mathrm{T}$ & . & . & . & . & . & . & . & . & . & & & & & & 1 \\
\hline 17 & . & G & . & & $\mathrm{T}$ & . & . & . & . & C & . & . & . & . & & & & & & 1 \\
\hline 18 & . & . & . & . & . & & . & . & . & C & . & . & . & . & & & & & & 1 \\
\hline 19 & . & . & . & . & $\mathrm{T}$ & . & C & . & . & . & . & . & . & . & & & & & & 1 \\
\hline 20 & . & . & . & . & . & . & C & . & G & . & . & . & . & . & & & & & & 1 \\
\hline 21 & . & . & . & $\mathrm{T}$ & $\mathrm{T}$ & . & & . & . & C & . & . & . & . & 8 & 8 & & 8 & & \\
\hline 22 & . & . & . & $\mathrm{T}$ & $\mathrm{T}$ & . & C & . & . & C & . & . & . & . & 6 & & & & & \\
\hline 23 & . & . & . & $\mathrm{T}$ & $\mathrm{T}$ & . & & . & . & C & . & . & C & . & 1 & & & & & \\
\hline 24 & . & . & . & $\mathrm{T}$ & $\mathrm{T}$ & . & C & $\mathrm{T}$ & . & C & . & G & . & C & 1 & & & & & \\
\hline 25 & . & . & . & $\mathrm{T}$ & $\mathrm{T}$ & . & C & . & . & C & G & . & . & . & 1 & & & & & \\
\hline 26 & . & . & . & $\mathrm{T}$ & $\mathrm{T}$ & C & . & . & . & C & . & . & . & . & & 1 & & & & \\
\hline 27 & A & . & A & $\mathrm{T}$ & $\mathrm{T}$ & . & . & . & . & C & . & . & . & . & & & & 9 & & \\
\hline
\end{tabular}


Table 2. Genetic diversity of Oratosquilla oratoria from the six samples from Hong Kong and its surrounding waters.

\begin{tabular}{|c|c|c|c|c|c|c|}
\hline Sample & $n$ & Latitude and longitude & $\begin{array}{l}\text { No. of polymorphic } \\
\text { sites }\end{array}$ & $\begin{array}{l}\text { No. of } \\
\text { haplotype }\end{array}$ & $\begin{array}{l}\text { Haplotype } \\
\text { diversity } \\
(h)\end{array}$ & $\begin{array}{l}\text { Nucleotide } \\
\text { diversity }(\pi)\end{array}$ \\
\hline E1 & 17 & $22^{\circ} 30.039^{\prime} \mathrm{N} 114^{\circ} 20.239^{\prime} \mathrm{E}$ & 6 & 5 & 0.684 & 0.0012 \\
\hline $\mathrm{E}_{2}$ & 17 & $22^{\circ} 30.541^{\prime} \mathrm{N} 114^{\circ} 21.385^{\prime} \mathrm{E}$ & 2 & 3 & 0.588 & 0.0007 \\
\hline $\mathrm{W}_{1}$ & 18 & $22^{\circ} 12.287^{\prime} \mathrm{N} 113^{\circ} 52.722^{\prime} \mathrm{E}$ & o & 1 & 0.000 & 0.0000 \\
\hline W2 & 17 & $22^{\circ} 13.069^{\prime} \mathrm{N} 113^{\circ} 56.945^{\prime} \mathrm{E}$ & 2 & 2 & 0.529 & 0.0012 \\
\hline $\mathrm{CW}$ & 23 & $22^{\circ} 22.868^{\prime} \mathrm{N} 113^{\circ} 48.726^{\prime} \mathrm{E}$ & 6 & 16 & 0.949 & 0.0033 \\
\hline $\mathrm{CE}$ & 7 & $22^{\circ} 29.985^{\prime} \mathrm{N} 114^{\circ} 30.670^{\prime} \mathrm{E}$ & 6 & 6 & 0.952 & 0.0035 \\
\hline $\begin{array}{l}\text { All localities } \\
\text { (overall) }\end{array}$ & 99 & & 14 & 27 & 0.886 & 0.0026 \\
\hline
\end{tabular}

Hong Kong waters. Apart from the fine-scale genetic patchiness, a larger difference in genetic diversity of $O$. oratoria was observed in samples obtained from open-waters than those obtained from sheltered bay sites, with a higher diversity recorded in the former.

Oratosquilla oratoria has a long planktonic larval phase ( $>1$ month; Hamano \& Matsuura, 1987), and the extensive transport and exchange of larvae across the South China Sea could be promoted by the Hainan Current (in summer) and the Kuroshio Current (in winter) (Morton \& Morton, 1983). Substantial larval dispersal between large-scale locations is expected and gene flow across Hong Kong and its surrounding waters within the South China Sea, therefore, does not appear to be restricted. As our findings demonstrated, a broad scale genetic homogeneity was observed $(\sim 100 \mathrm{~km})$. Such low levels of genetic differentiation over a geographical scale have also been described for other stomatopods (Barber et al., 2002a; Lindstrom, 2003). Similar to O. oratoria, the coral Platygyra sinensis with planktonic larvae also exhibited a relatively homogeneous genetic structure across Hong Kong waters (Ng \& Morton, 2003).

On the other hand, an unexpected fine-scale, un-patterned genetic variability was recorded, and an extremely low haplotype diversity in Oratosquilla oratoria was observed in the two sheltered sites from western waters of Hong Kong. A small scale genetic variation was also reported for the stalked barnacle Ibla cumingi in Hong Kong waters, being attributed to the combined effect of a short lecithotrophic larval period and local hydrographic characters (Leung, 2002). Those marine organisms that demonstrate substantial larval dispersal with large-scale genetic homogeneity, but have genetic heterogeneity among populations over a small spatial scale, have been identified as showing 'chaotic genetic patchiness' (Johnson \& Black, 1982; Watts et al., 1990). Such genetic patchiness could be explained by several hypotheses. Firstly, it may relate to a 'sweepstakes'-pattern of reproduction (Hellberg et al., 2002; Hedgecock et al., 2007). Many high fecundity and free-spawning marine species, including O. oratoria, could experience extremely large variance in individual reproductive success when sweepstakes-chance reproductive activity matches oceanographic conditions (Li \& Hedgecock, 1998; Lundy et al., 2000). In such a case, the successful offspring of a population may be randomly contributed to by a limited number of reproductive adults, and the resulting low effective number of offspring may lead to the occurrence of small-scale patchy genetic structures. It has been reported that $O$. oratoria demonstrates high reproductive variability in Hong Kong waters (Lui, 2005). For instance, the key local recruitment of $O$. oratoria first occurs during the summer months of May-September in western waters with a minor recruitment pulse in November. Conversely, eastern water individuals were mainly recruited during winter months from January-March with a minor summer recruitment in July (Lui, 2005). During the monsoon rainy summer period (May-August); a lower percentage occurrence of ovigerous females was consistently observed in western waters than eastern ones and this might be attributed to low salinities (average salinity: $\sim 10$ to $20 \mathrm{ppt}$; Yin \& Harrison, 2007) in the former due to the summer discharge of freshwater from the Pearl River. Under such harsh conditions, larvae of O. oratoria might suffer from hypo-osmotic stress and be restrained by the physical barrier of salinity stratification. If so, this may support the sweepstakes' concept.

Larval movement can be greatly influenced by variations in environmental variables such as current direction and hydrographic barriers, causing genetic differentiation among recruits (Hedgecock, 1986; Kordos \& Burton, 1993; Morgan, 1995). Although Oratosquilla oratoria larvae have high dispersal potential, freshwater runoff from the Pearl River Estuary in western Hong Kong may form a barrier to their dispersal and western SB sites ( $\mathrm{W}_{1}$ and $\mathrm{W}_{2}$ ) may thus become a local retention zone. Estuarine circulation is known to act as a barrier to larval mixing (Roughgarden et al., 1988). The population genetic structures of the sea star, Coscinasterias muricata, for instance, were affected by freshwater influxes and distinctive estuarine circulations in New Zealand fiords (Perrin et al., 2004), and a similar pattern has also been observed in other estuarine organisms (amphipods, horseshoe crabs and polychaetes; Bilton et al., 2002). Furthermore, larval dispersal profiles can be influenced by behavioural adaptations to oceanographic conditions (Young, 1995), especially vertical migration (Dame \& Allen, 1996). Stomatopod larvae are strong swimmers and may not disperse as passive particles (Barber et al., 2002b). They also exhibit vertical migration (Reaka \& Manning, 1981) which may further limit dispersal (Robichaux et al., 1981). These aforementioned factors could concomitantly influence larval movement and shape the genetic patchiness pattern of O. oratoria in Hong Kong waters.

Both pre- and post-settlement mortalities may play roles in shaping the genetic structures of a marine species within a small spatial and/or temporal scale (Johnson \& Black, 1984; Johannesson et al., 1995). Kodama et al. (2006) reported that Oratosquilla oratoria juveniles in Tokyo Bay were sensitive to dissolved oxygen levels and thus massive mortalities occurred in shallow water areas when summer hypoxia events persisted. A similar large scale mortality may also happen in Hong Kong stomatopod settlers during summers 
A

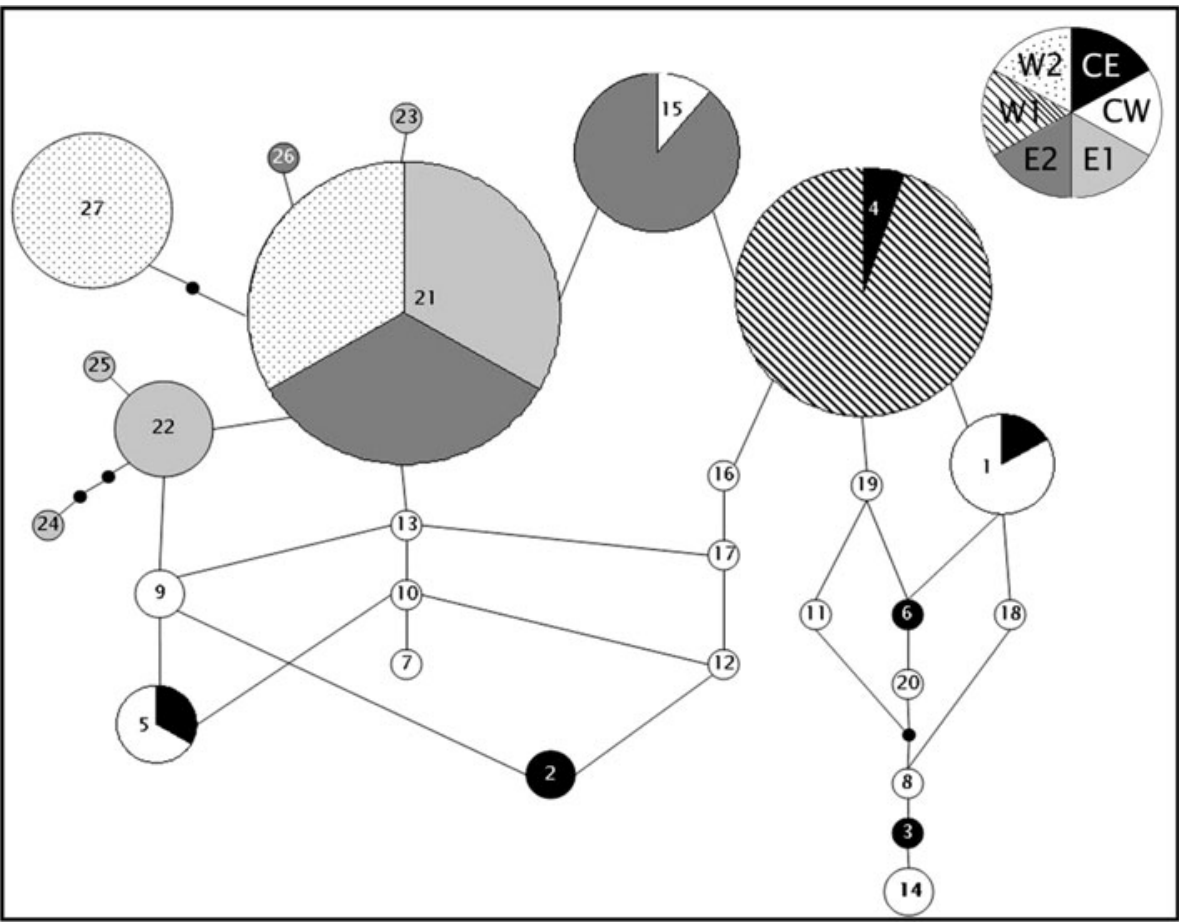

B

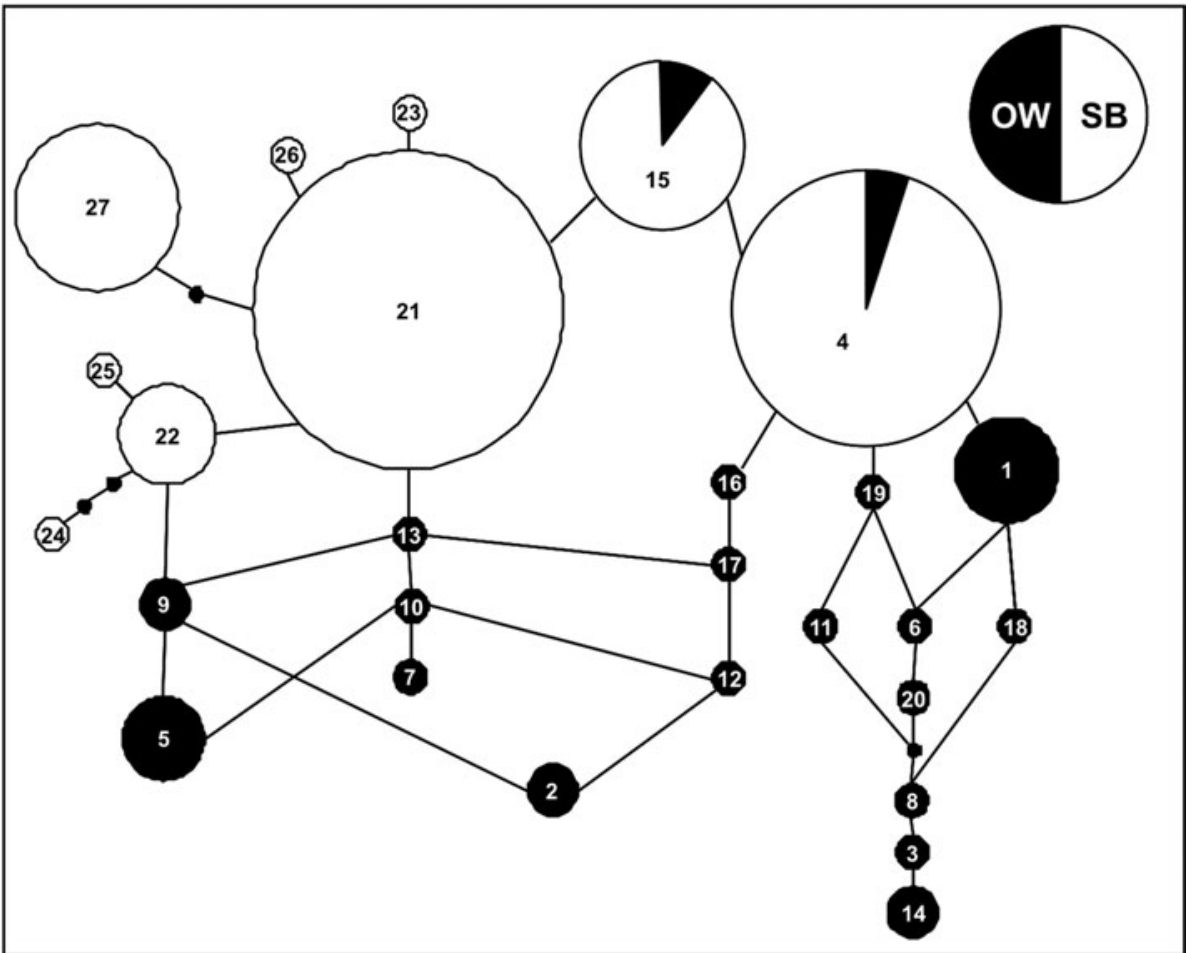

Fig. 2. Minimum spanning network (MSN) of the mtDNA control region sequences based on the grouping of sites from (A), the six locations and (B), the open-waters $(\mathrm{OW})$ and sheltered bays (SB). Each haplotype is defined by its corresponding number. The area of each circle is proportional to the frequency of that haplotype in the total sample. Shared haplotypes among sampling locations were represented as frequency diagrams. Substitution between haplotypes is represented by a line. Hypothetical missing haplotypes are represented as small filled circles.

when hypoxia events are more common, especially in the western waters (Yin et al., 2004). Results of the present study, however, cannot conclude whether the observed genetic patchiness is a short-term pattern, i.e. when the unmixed portion of the population is not robust enough to sustain a lasting genetic structure (Selkoe et al., 2006), or a long-term pattern, i.e. when genetic variations between cohorts accumulate over time (Maes et al., 2006).

Haplotype sequences were closely related in all samples of Oratosquilla oratoria, and the minimum spanning network formed a star-shaped phylogeny around a few prevalent haplotypes. A star-shaped genealogy is often associated with 
Table 3. Pairwise $F_{\mathrm{ST}}$ values between samples of Oratosquilla oratoria from different regions. Significant differences between pairs, after 10,100 random permutations, are indicated by asterisk $(s):{ }^{* *} P<0.01$; ${ }^{* * *} P<0.001$.

\begin{tabular}{lllllll}
\hline & $\mathrm{CE}$ & $\mathrm{CW}$ & $\mathrm{E} 1$ & $\mathrm{E} 2$ & $\mathrm{~W}_{1}$ & $\mathrm{~W}_{2}$ \\
\hline $\mathrm{CE}$ & - & & & & & \\
$\mathrm{CW}$ & 0.0065 & - & & & & \\
$\mathrm{E} 1$ & $0.2037^{* *}$ & $0.1783^{* * *}$ & - & & & \\
$\mathrm{E}_{2}$ & $0.2633^{* *}$ & $0.2072^{* * *}$ & $0.1831^{* *}$ & - & & \\
$\mathrm{W}_{1}$ & $0.6307^{* * *}$ & $0.4928^{* * *}$ & $0.6654^{* * *}$ & $0.7125^{* * *}$ & - & \\
$\mathrm{W}_{2}$ & $0.3010^{* *}$ & $0.2502^{* * *}$ & $0.2208^{* *}$ & $0.2822^{* *}$ & $0.7415^{* *}$ & - \\
\hline
\end{tabular}

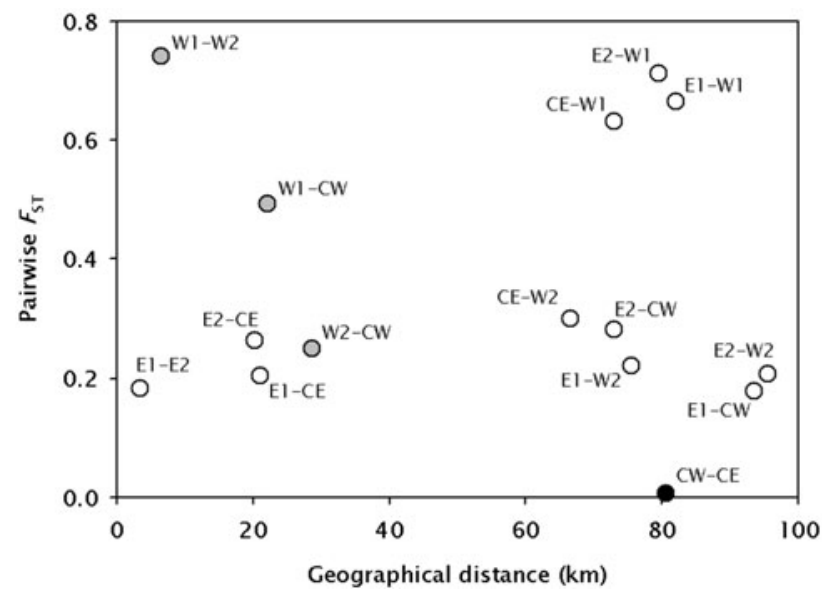

Fig. 3. A plot of pairwise $F_{\mathrm{ST}}$ between samples of Oratosquilla oratoria from different regions against their pairwise geographical distances. Letters next to each symbol represent the pairwise relationship of samples from the specified regions.

Table 4. Analysis of molecular variance comparing all six samples of Oratosquilla oratoria based on the grouping of the six samples from: (1) eastern, EW (CE, E1 and E2) and western waters, WW (CW, W1 and $\mathrm{W}_{2}$ ); and (2) open-water, $\mathrm{OW}$ (CE and $\mathrm{CW}$ ) and sheltered bay, $\mathrm{SB}\left(\mathrm{W}_{1}, \mathrm{~W}_{2}, \mathrm{E}_{1}\right.$ and $\left.\mathrm{E}_{2}\right)$. Significant sources of variation, after 16,000 random permutations, are indicated by asterisk(s): ${ }^{* * *} P<0.001$.

\begin{tabular}{|c|c|c|c|c|c|}
\hline $\begin{array}{l}\text { Source of } \\
\text { variation }\end{array}$ & df & $\begin{array}{l}\text { Sum of } \\
\text { squares }\end{array}$ & $\begin{array}{l}\text { Variance } \\
\text { components }\end{array}$ & $\begin{array}{l}\text { Percentage } \\
\text { of variation } \\
(\%)\end{array}$ & $\Phi$ indices \\
\hline $\begin{array}{l}\text { Among groups } \\
\text { (EW versus } \\
\text { WW })\end{array}$ & 1 & 2.859 & -0.011 & -2.44 & $\begin{array}{l}\Phi_{\mathrm{CT}}: \\
\quad-0.024\end{array}$ \\
\hline $\begin{array}{l}\text { Among samples } \\
\text { within } \\
\text { groups }\end{array}$ & 4 & 12.831 & 0.182 & 38.83 & $\begin{array}{l}\Phi_{\mathrm{SC}}: \\
\quad 0.379^{* * *}\end{array}$ \\
\hline Within samples & 93 & 27.704 & 0.230 & 63.62 & $\begin{array}{l}\Phi_{\mathrm{ST}}: \\
\quad 0.364^{* * *}\end{array}$ \\
\hline Total & 98 & 43.394 & 0.468 & & \\
\hline $\begin{array}{l}\text { Among groups } \\
\text { (OW versus } \\
\text { SB) }\end{array}$ & 1 & 2.956 & -0.019 & -4.07 & $\begin{array}{l}\Phi_{\mathrm{CT}}: \\
\quad-0.041\end{array}$ \\
\hline $\begin{array}{l}\text { Among samples } \\
\text { within } \\
\text { groups }\end{array}$ & 4 & 12.734 & 0.185 & 39.84 & $\begin{array}{l}\Phi_{\mathrm{SC}}: \\
\quad 0.383^{* * *}\end{array}$ \\
\hline Within samples & 93 & 27.704 & 0.298 & 64.23 & $\begin{array}{l}\Phi_{\mathrm{ST}}: \\
\quad 0.358^{* * *}\end{array}$ \\
\hline Total & 98 & 43.394 & 0.464 & & \\
\hline
\end{tabular}

demographic expansion of a single ancestral population (Slatkin \& Hudson, 1991). High haplotype diversity but low nucleotide diversity was observed in samples of O. oratoria. This has also been recorded for other stomatopods (Barber et al., 2002a, b; Lindstrom, 2003) and echinoderms (Perrin et al., 2004), and is closely linked to recent, rapid, population expansion from a small, effective, ancestral population. When population size increases rapidly following environmental disturbances, haplotype diversity can usually recover via mutation, whereas nucleotide diversity remains low as there is not sufficient time to accumulate large sequence differences between haplotypes (Avise, 2000).

The Hong Kong marine environment is highly disturbed in terms of pollution and fisheries activities such as trawling (Morton \& Blackmore, 2001; Leung, 2003). Mantis shrimps including Oratosquilla oratoria are important commercial species and subject to high fishing pressures. It has been reported that severe overfishing could reduce the genetic diversity of marine species (Hauser et al., 2002). A summer fishing moratorium (May-July) has been implemented in the South China Sea since 1999. Fish catch rate has consequently increased, and fish populations appear to be recovering in some of China's waters (AFCD, 2004). Hong Kong, however, has no fishing ban or other common fishery management tools such as a fishing quota system and regulations related to fishing net mesh size. While the problem of overfishing persists, it is plausible that frequent bottom trawling activities could be one of the major driving forces leading to the observed fine-scale genetic patchiness of $O$. oratoria samples in Hong Kong waters.

In conclusion, this mtDNA sequence analysis has successfully revealed the first population genetic structure study of one of the most commercially important stomatopods, Oratosquilla oratoria, in Hong Kong waters. Genetic analysis has demonstrated an expected homogeneity of genetic structure in meso-scale distance, but revealed a high genetic variation between samples with a patchiness pattern at the fine-scale. Moreover, an extreme genetic diversity was found among different samples. The patchy patterns could be explained by the high variability in reproductive success of $O$. oratoria, locally dynamic hydrographic conditions and high post-settlement mortality in Hong Kong waters.

\section{ACKNOWLEDGEMENTS}

This research was partially supported by a seed grant from the University of Hong Kong (Project No. 1020-5213) to K.M.Y.L. The authors would like to thank Dr Jasmine Ng for her useful comments on the manuscript. The staff, undergraduates and postgraduates in the Division of Ecology \& Biodiversity, School of Biological Sciences, University of Hong Kong are thanked for their help with field sampling.

\section{REFERENCES}

AFCD (Agriculture, Fisheries and Conservation Department) (2004) Consultation Paper on the Proposed Amendment of the Fisheries Protection Ordinance, Cap 171 for the Establishment of a Regulatory Framework for Fishing Activities in Hong Kong Waters. Hong Kong: AFCD, Hong Kong SAR Government. 
Ahyong S.T. (2001) Revision of the Australian stomatopod Crustacea Records of the Australian Museum Supplement 26, 8-193.

Avise J.C. (2000) Phylogeography: the history and formation of species. Massachusetts: Harvard University Press.

Bagley M.J. and Gall A.E. (1998) Mitochondrial and nuclear DNA sequence variability among populations of rainbow trout (Oncorhynchus mykiss). Molecular Ecology 7, 945-961.

Barber P.H., Moosa M.K. and Palumbi S.R. (2002a) Rapid recovery of genetic diversity of stomatopod populations on Krakatau: temporal and spatial scales of marine larval dispersal. Proceedings of the Royal Society of London 269, 1591-1597.

Barber P.H., Palumbi S.R., Erdmann M.V. and Moosa M.K. (2002b) Sharp genetic breaks among populations of Haptosquilla pulchella (Stomatopoda) indicate limits to larval transport: patterns, causes, and consequences. Molecular Ecology 11, 659-674.

Bilton D.T., Paula J. and Bishop J.D.D. (2002) Dispersal, genetic differentiation and speciation in estuarine organisms. Estuarine, Coastal and Marine Science 55, 937-952.

Burton R.S. and Feldman M. (1982) Population genetics of coastal and estuarine invertebrates: does larval behaviour influence population structure? In Kennedy V.S. (ed.) Estuarine comparisons. New York: Academic Press, pp. 537-551.

Clement K.A., Posada D. and Crandall K.A. (2000) TCS: a computer program to estimate gene genealogies. Molecular Ecology 9, 16571659 .

Crandall K.A., Templeton A.R. and Sing C.F. (1994) Intraspecific cladogram estimation: problems and solutions. In Scotland R.W., Siebert D.J. and Williams D.M. (eds) Models in phylogeny and reconstruction Oxford: Clarendon Press, pp. 273-297.

Dame R.F. and Allen D.M. (1996) Between estuaries and the sea. Journal of Experimental Marine Biology and Ecology 200, 169-185.

Excoffier L., Laval G. and Schneider S. (2005) Arlequin ver. 3.0: an integrated software package for population genetics data analysis Evolutionary Bioinformatics Online 1, 47-50.

Guo S.W. and Thompson E.A. (1992) Performing the exact test of Hardy-Weinberg proportion for multiple alleles. Biometrics 48 $361-372$.

Hamano T. and Matsuura S. (1987) Egg size, duration of incubation, and larval development of the Japanese mantis shrimp in the laboratory. Bulletin of the Japanese Society of Scientific Fisheries 53, 23-39.

Hauser L., Adcock G.J., Smith P., Bernal Ramirez J.H. and Carvalho R. (2002) Loss of microsatellite diversity and low effective population size in an overexploited population of New Zealand snapper (Pagrus auratus). Proceedings of the National Academy of Sciences of the United States of America 99, 11742-11747.

Hedgecock D. (1986) Is gene flow from pelagic larval dispersal important in the adaptation and evolution of marine invertebrates? Bulletin of Marine Science 39, 550-565.

Hedgecock D., Launey S., Pudovkin A.I., Naciri Y., Lapègue S. and Bonhomme F. (2007) Small effective number of parents $\left(N_{b}\right)$ inferred for a naturally spawned cohort of juvenile European flat oysters Ostrea edulis. Marine Biology 150, 1173-1182.

Hellberg M.E., Burton R.S., Neigel J.E. and Palumbi S.R. (2002) Genetic assessment of connectivity among marine populations. Bulletin of Marine Science 70, S273-290.

Hoelzel A.R. and Green A. (1992) Analysis of population-level variation by sequencing PCR-amplified DNA. In Hoelzel A.R. (ed.) Molecular genetic analysis of populations: a practical approach. Oxford: Oxford University Press, pp. 159-186.
Johannesson K., Johannesson B. and Lundgren U. (1995) Strong natural-selection causes microscale allozyme variation in a marine snail. Proceedings of the National Academy of Sciences of the United States of America 92, 2602-2606.

Johnson M.S. and Black R. (1982) Chaotic genetic patchiness in an intertidal limpet, Siphonaria sp. Marine Biology 70, 157-164.

Johnson M.S. and Black R. (1984) Pattern beneath the chaos: the effect of recruitment on genetic patchiness in an intertidal limpet. Evolution 38 , $1371-1383$.

Kenchington E., Heino M. and Nielsen E.E. (2003) Managing marine genetic diversity: time for action? ICES Journal of Marine Science 60, $1172-1176$.

Kodama K., Horiguchi T., Kume G., Nagayama S., Shimizu T., Shiraishi H., Morita M. and Shimizu M. (2006) Effects of hypoxia on early life history of the stomatopod Oratosquilla oratoria in a coastal sea. Marine Ecology Progress Series 324, 197-206.

Kordos L.M. and Burton R.S. (1993) Genetic differentiation of Texas Gulf Coast populations of the blue crab Callinectes sapidus. Marine Biology 117, 227-233.

Kumur S. Tamura K. and Nei M. (2004) MEGA 3.1: Integrated software for molecular evolutionary genetics analysis and sequence alignment. Briefings in Bioinformatics 5, 150-163.

Leung T.Y. (2002) The ecology and reproductive biology of two intertidal barnacles, Capitulum mitella and Ibla cumingi (Cirripedia: Pedunculata), in Hong Kong. PhD thesis. The University of Hong Kong, Hong Kong.

Leung A.W.Y. (2003) Overfishing and the fishing industry in Hong Kong. In Morton B. (ed.) Perspectives on marine environmental change in Hong Kong, 1977-2001. Hong Kong: Hong Kong University Press, pp. $719-743$.

Li G. and Hedgecock D. (1998) Genetic heterogeneity, detected by PCR-SSCP, among samples of larval Pacific oysters (Crassostrea gigas) supports the hypothesis of large variance in reproductive success. Canadian Journal of Fisheries and Aquatic Sciences 55, $1025-1033$

Lindstrom K.S. (2003) Aspects of behaviour, population genetics, and phylogeny of stomatopod crustaceans. $\mathrm{PhD}$ thesis. The University of California, Berkeley, USA.

Lui K.K.Y. (2005) Ecology of commercially important stomatopods in Hong Kong. MPhil thesis. The University of Hong Kong, Hong Kong.

Lui K.K.Y., Ng J.S.S. and Leung K.M.Y. (2007) Spatio-temporal variations in diversity and abundance of commercially important Decapoda and Stomatopoda in subtropical Hong Kong Waters. Estuarine, Coastal and Shelf Science 72, 635-647.

Lundy C.J., Rico C. and Hewitt G.M. (2000) Temporal and spatial genetic variation in spawning grounds of European hake (Merluccius merluccius) in the Bay of Biscay. Molecular Ecology 9, 2067-2079.

Maes G.E., Pujolar J.M., Hellemans B. and Volckaert F.A.M. (2006) Evidence for isolation by time in the European eel (Anguilla anguilla L.). Molecular Ecology 15, 2095-2107.

McEdward L. (1995) The ecology of marine invertebrate larvae. Boca Raton, FL: CRC Press.

Meyer A. (1994) Molecular phylogenetic studies of fish. In Beaumont A.R. (ed.) Genetics and evolution of aquatic organisms. London: Chapman \& Hall, pp. 219-249.

Morgan S.A. (1995) Life and death in the plankton: larval mortality and adaptation. In: McEdward L. (ed.) Ecology of marine invertebrate larvae. New York: CRC Press, pp. 279-322.

Morgan S.G. and Goy J.W. (1987) Reproduction and larval development of the mantis shrimp Gonodactylus bredini (Crustacea: Stomatopoda) 
maintained in the laboratory. Journal of Crustacean Biology 7 , 595-618.

Morton B. and Blackmore G. (2001) South China Sea. Marine Pollution Bulletin 42, 1236-1263.

Morton B. and Morton J. (1983) The sea shore ecology of Hong Kong. Hong Kong: Hong Kong University Press.

Ng W.C. and Morton B. (2003) Genetic structure of the scleractinian coral Platygyra sinensis in Hong Kong. Marine Biology 143, 963-968.

Nei M. (1987) Molecular evolutionary genetics. New York: Columbia University Press.

Palumbi S.R. (1994) Genetic divergence, reproductive isolation, and marine speciation. Annual Review of Ecology and Systematics 25, 547-572.

Palumbi S.R. (2003) Population genetics, demographic connectivity, and the design of marine reserves. Ecological Applications 13, 146-158.

Perrin C., Wing S.R. and Roy M.S. (2004) Effects of hydrographic barriers on population genetic structure of the sea star Coscinasterias muricata (Echinodermata, Asteroidea) in the New Zealand fjords. Molecular Ecology 13, 2183-2195.

Provenzano A.J. and Manning R.B. (1978) Studies on development of stomatopod crustacean II. The later larval stages of Gonodactylus oerstedii (Hansen) reared in the laboratory. Bulletin of Marine Science 28 297-315.

Reaka M.L. and Manning R.B. (1981) The behaviour of stomatopod crustaceans and its relationship to rates of evolution. Journal of Crustacean Biology 1, 309-327.

Refseth U.H., Nesbø C.L., Stacy J.E., Vøllestad L.A., Fjeld E. and Jakobsen K.S. (1998) Genetic evidence for different migration routes of freshwater fish into Norway revealed by analysis of current perch (Perca fluviatilis) populations in Scandinavia. Molecular Ecology 7, 1015-1027.

Robichaux D.M., Cohen A.C., Reaka M.L. and Allen D. (1981) Experiments with zooplankton on coral reefs, or, will the real demersal plankton please come up? Marine Ecology 2, 77-94.

Roughgarden J., Gaines S. and Possingham H. (1988) Recruitment dynamics and complex life cycles. Science 241, 1460-1466.
Selkoe K.A., Gaines S.D., Caselle J.E. and Warner R.R. (2006) Current shifts and kin aggregation explain genetic patchiness in fish recruits. Ecology 87, 3082-3094.

Slatkin M. and Hudson R.R. (1991) Pairwise comparisons of mitochondrial DNA sequences in stable and exponentially growing populations. Genetics 129, 555-562.

Tajima F. (1983) Evolutionary relationship of DNA sequences in finite populations. Genetics 105, 437-460.

Tzeng T.D., Yeh S.Y. and Hui C.F. (2004) Population genetic structure of the Kuruma prawn (Penaeus japonicus) in East Asia inferred from mitochondrial DNA sequences. ICES Journal of Marine Science $61,912-920$.

Watts R.J., Johnson M.S. and Black R. (1990) Effects of recruitment on genetic patchiness in the urchin Echinometra mathaei in Western Australia. Marine Biology 105, 145-151.

Wright S. (1951) The genetical structure of populations. Annals of Eugenics 15, 323-354.

Yin K. and Harrison P.J. (2007) Influence of the Pearl River estuary and vertical mixing in Victoria Harbor on water quality in relation to eutrophication impacts in Hong Kong waters. Marine Pollution Bulletin 54, 646-656.

Yin K.D., Lin Z.F. and Ke Z.Y. (2004) Temporal and spatial distribution of dissolved oxygen in the Pearl River Estuary and adjacent coastal waters. Continental Shelf Research 24, 1935-1948.

and

Young C.M. (1995) Behavior and locomotion during the dispersal phase of larval life. In McEdward L. (ed.) Ecology of marine larvae. New York: CRC Press, pp. 249-278.

\section{Correspondence should be addressed to:}

P.T.Y. Leung

The Swire Institute of Marine Science, and Division of Ecology \& Biodiversity School of Biological Sciences

University of Hong Kong

Pokfulam, Hong Kong

People's Republic of China

email: tyleung@graduate.hku.hk 